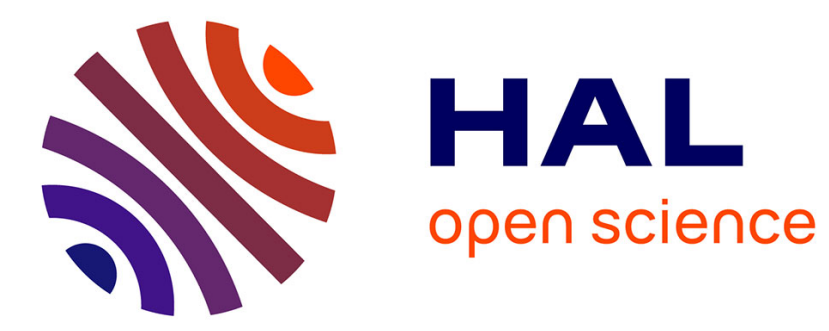

\title{
School starting age and nutritional outcomes: Evidence from Brazil
}

\author{
Pierre Levasseur
}

\section{To cite this version:}

Pierre Levasseur. School starting age and nutritional outcomes: Evidence from Brazil. Economics and Human Biology, 2022, 45, 10.1016/j.ehb.2021.101104 . hal-03511976

\section{HAL Id: hal-03511976 \\ https://hal.inrae.fr/hal-03511976}

Submitted on 5 Jan 2022

HAL is a multi-disciplinary open access archive for the deposit and dissemination of scientific research documents, whether they are published or not. The documents may come from teaching and research institutions in France or abroad, or from public or private research centers.
L'archive ouverte pluridisciplinaire HAL, est destinée au dépôt et à la diffusion de documents scientifiques de niveau recherche, publiés ou non, émanant des établissements d'enseignement et de recherche français ou étrangers, des laboratoires publics ou privés. 


\title{
School starting age and nutritional outcomes: Evidence from Brazil
}

\author{
Pierre Levasseur \\ UMR 1048 SADAPT, INRAE, AgroParistech, Université Paris-Saclay, France
}

\section{A R T I C L E I N F O}

\section{Key words:}

Brazil

Schooling

Childhood overweight

Height-for-age

BMI-for-age

\begin{abstract}
A B S T R A C T
Recent studies reported that the age of primary school enrolment is a major driver of educational achievement and adult income, but its impacts on childhood health and nutrition remain largely unknown, particularly in developing countries where childhood stunting and overweight coexist. In Brazil, children are supposed to enrol in primary school the year they turn 6. Using a database of middle school students in Brazil based on a 2015 survey, I implemented an instrumental variables strategy using quasi-exogenous variations in the students' birthdates to isolate the impact of late primary school enrolment (i.e., older than 6 when enrolled) on height-forage and body mass-for-age indicators. Overall, late enrolment has protective effects against hazardous weight gain $(-0.14 \mathrm{z}$-score unit) but significantly increases the risk of moderate stunting (by $1.5 \%$ points). Heterogeneity in family backgrounds may explain these results. Indeed, delayed school enrolment is particularly detrimental for the nutritional status of students from underprivileged settings. In terms of public policy, rather than changing school starting age, this study highlights the importance of focusing on pathways to fight both stunting and overweight conditions in Brazilian children.
\end{abstract}

\section{Introduction}

School starting age is considered as an important instrument of public policy to improve the aggregated level of human capital and promote a country's economic development (Ryu et al., 2020). While the great majority of studies focused on the effects of delayed school enrolment on educational attainment and mental health outcomes, I propose to analyse its impacts on health and nutritional outcomes.

All countries have administrative birthdate cut-offs for school enrolment, providing a quasi-experimental design that makes it possible to statistically compare children who start school younger (around age 5.5) with their counterparts who start 1 year older (around age 6.5) (Angrist and Krueger, 1991). Using the quasi-random variation in school starting age induced by birthdate, the labour economics literature emphasized the positive effects of delayed school enrolment on educational achievement and labour market outcomes, at least for wealthy countries (Bedard and Dhuey, 2006; Datar, 2006; McEwan and Shapiro, 2008). ${ }^{1}$ In addition to showing greater readiness for learning and integrating into the school environment, older children are less vulnerable to negative school externalities (e.g. social stigmatization, peer effects) than their younger counterparts (Black et al., 2011; Stipek, 2002).
Research in health economics considered mental health as a potential mediator in the relationship between school starting age and socioeconomic success. Indeed, several studies found that delayed school enrolment reduces the risk of behavioural problems such as inattention, hyperactivity, and other disruptive behaviours (Balestra et al., 2020; Dee and Evans, 2003; Dee and Sievertsen, 2018; Mühlenweg et al., 2012). However, the impact of school starting age on other health dimensions such as physical health and nutrition remains largely unknown and understudied (Bahrs and Schumann, 2020).

Although several studies analysed the effect of school exposure on childhood obesity, namely when junk food is available in school (Anderson and Butcher, 2006; Schanzenbach, 2009), limited research has focused on the nutritional consequences of school starting age. To my knowledge, Anderson et al. (2011), Zhang and Zhang (2011), and Chang and Jung (2017) were the first to compare weight outcomes between early- and late-enrolled students in the US. Mak (2018) applied a similar approach to the Australian context. However, each study reported different findings. While Zhang and Zhang (2011) and Chang and Jung (2017) found a higher risk of being obese among late-enrolled girls and boys, respectively, Mak (2018) observed a higher risk of being obese among early-enrolled students (especially for girls), and Anderson et al.

\footnotetext{
* Correspondence address: UMR 1048 SADAPT, AgroParistech, 16 rue Claude Bernard, 75231 cedex 05 Paris, France.

E-mail address: pierre.levasseur@inrae.fr.

${ }^{1}$ In the case of developing countries, Ryu et al. (2020) nuanced these findings. They found that advancing the age of primary school enrolment from 7 to 6 years old had positive effects on schooling performance in Brazil.
} 
(2011) found no significant weight gap between early and delayed enrolments (independent of gender). Given this uncertainty in the nutritional impact of school starting age, more research is needed to understand how delaying school entrance may affect childhood bodyweight. The results are expected to be even more variable in poorer countries where stunting often persists and childhood overweight dramatically increases (Doak et al., 2000). In fact, late school enrolment systematically delays the exposure to (often free) school meals and may make children dependent on (risky) family feeding behaviours longer (Thibault et al., 2013); this is relevant in terms of calorie intake and nutrient quality and diversity, especially in underprivileged settings (Anderson et al., 2011). In line with this issue, Horta et al. (2019) reported in poor Brazilian areas higher consumption of fruit and vegetables versus lower consumption of ultra-processed food and soft drinks among children who usually receive school meals compared to children who do not (usually) use school food services. ${ }^{2}$ Malnourishment in young childhood significantly impairs physical and mental growth and may contribute to poor lifelong health. In Ghana, Gelli et al. (2019) showed that receiving school meals decreased the risk of stunting by significantly increasing the average height-for-age of primary school children aged between 5 and 8, especially in households living below the poverty line. In rural South Africa, a school program that provides free school meals was shown to reduce both the stunting and overweight rates among children aged from 6 to 12 (Graham et al., 2018).

Late school enrolment is also likely to increase childcare expenditure, which may directly impair household food security. In such cases, early school attendance would act as a social protection for underprivileged families by alleviating household food pressures (Bakhshinyan et al., 2019). Likewise, the literature suggests that a child's school enrolment increases his/her mother's employment, especially for single mothers who then do not have to provide constant care for younger children (Gelbach, 2002; Berlinski and Galiani, 2007). Hence, in addition to incurring extra childcare costs, late school enrolment is likely to delay parental employment and reduce family incomes over a period. Such transitory constraints could make underprivileged households highly vulnerable to food insecurity episodes, which may impact the child's nutritional status and growth (Leete and Bania, 2010).

The aim of this study is to fill the literature gap on the potential impacts of school starting age on stunting and body mass indicators in the context of a developing country. Based on a rich and recent survey targeting a large sample of Brazilian middle school children (aged 11-15), I implement an instrumental variables (IV) strategy using assumed exogenous variations in birthdate to isolate the impacts of delayed school enrolment. To measure stunting and body mass indicators, I adjust the objective measurements of height and weight collected by the survey's trained staff for age and gender. The focus on Brazilian middle school children makes this work highly original since the potential effects of school starting age on nutritional outcomes are particularly uncertain in the context of developing countries, where child stunting and overweight often coexist (Doak et al., 2000).

Overall, the results show that early enrolment increases the ageadjusted body mass index (BMI-for-age) and the risk of being overweight, especially for boys. These findings echo previous studies that reported a protective effect of delayed enrolment against weight gain (Mak, 2018), educational failure, and mental health disorders (Black et al., 2011; McEwan and Shapiro, 2008). However, this protective effect

\footnotetext{
${ }^{2}$ Similar findings were also observed in wealthy countries. For example, von Hippel et al. (2007) observed a higher increase in young US children weight during summer vacations than during the kindergarten and first-grade school years, suggesting that school exposure has a protective effect against weight gain. Likewise, comparing school meals and packed lunches in English primary schools, Evans et al. (2016) found that the former are of better nutritional quality, being richer in fibers, folates, proteins, zinc with lower sodium and sugar levels.
}

may only concern children from privileged family backgrounds. I find that late enrolment reduces BMI-for-age and height-for-age and increases stunting, especially among individuals from underprivileged backgrounds. In contrast, late-enrolled children from privileged background are less likely to be underweight or overweight and have no stunting risks. Several factors may explain this socioeconomic heterogeneity in the nutritional effect of school starting age. First, early enrolment can have health benefits for children from underprivileged background insofar as delayed enrolments may involve extra costs related to longer childcare and parental unemployment (e.g. reducing household food insecurity). Likewise, one can assume that late enrolment delays access to free and dietetic school meals and hence impairs child growth in underprivileged households because of potential nutritional deficiencies.

The rest of the article is organized as follows. Section 2 describes the Brazilian education system. In Section 3, I describe the data and methods. The results are presented in Section 4, and finally, in Section 5, I conclude and provide public policy recommendations.

\section{The Brazilian education system}

The Brazilian education system is divided into three school levels: preschool (three grades), elementary school (including five grades of primary school and four grades of middle school) and high school (three grades). Preschool education is entirely optional and rarely free in Brazil. Only primary school and middle school are free and compulsory. In 2006 , reform $n^{\circ} 11.274 / 2006$ changed the age of primary school enrolment by adding one grade and advancing the age of primary school enrolment to 6 years old. Before the 2006 reform, compulsory school ranged from age 7-14 (including four grades of primary school and four grades of middle school). Brazilian states had until 2010 to comply; but most Brazilian schools already did so by 2007 (Ryu et al., 2020).

In Brazil, the school year generally lasts from February to December (July is free for half-year holidays and January is free for annual holidays). Since 2006, Brazilian children are eligible for first enrolment in primary school if they turn 6 before March 31 of the same year (Fig. 1). ${ }^{3}$ This national rule creates a 1-year difference between children born in April (who start school at 6 years old and 10 months) and children born in March (who start school at 5 years old and 10 months). However, the reality is not so clear cut: many Brazilian states continued to choose their own cut-off date for primary school entry and did not uniformly apply the federal date of March 31. According to Ryu et al. (2020), most of states selected a cut-off date between February and April.

\section{Data and methods}

\subsection{Data}

The data were from the second sample of PeNSE 2015 (National Survey of Student Health). Designed by the Brazilian Institute of Geography and Statistics (Portuguese acronym IBGE) and the Health Ministry and supported by the Education Ministry, this was the third crosssectional survey (the two first were conducted in 2009 and 2012). The sample included 371 public and private schools and more than 16,000 students aged from 11 to 19 , but it is only representative of the Brazilian population aged from 13 to 17 (Oliveira et al., 2017). The survey was directly administered to students in the form of a numerical questionnaire and provides a wealth of information on birthdate (month and year of birth), ${ }^{4}$ health-related events and behaviours, as well as about family backgrounds such as owned assets and maternal education. In addition, it provides clinical data such as the height and weight of individuals

\footnotetext{
${ }^{3}$ Before 2006, students used to start primary education in the calendar year they turned 7.

${ }^{4}$ Unfortunately, exact birth dates are not available in the data.
} 


\begin{tabular}{|c|c|c|c|c|c|c|c|c|c|c|c|c|c|c|c|c|c|c|c|c|c|c|c|c|c|c|c|}
\hline \multirow[b]{3}{*}{ Age in 2015} & \multicolumn{12}{|c|}{ Middle school } & \multicolumn{15}{|c|}{ Primary school } \\
\hline & \multicolumn{3}{|c|}{$\begin{array}{c}\text { 9th } \\
\text { grade }\end{array}$} & \multicolumn{3}{|c|}{$\begin{array}{c}\text { 8th } \\
\text { grade }\end{array}$} & \multicolumn{3}{|c|}{$\begin{array}{c}\text { 7th } \\
\text { grade }\end{array}$} & \multicolumn{3}{|c|}{$\begin{array}{c}6 \text { th } \\
\text { grade }\end{array}$} & \multicolumn{3}{|c|}{$\begin{array}{c}5 \text { th } \\
\text { grade }\end{array}$} & \multicolumn{3}{|c|}{$\begin{array}{c}4 \text { th } \\
\text { grade }\end{array}$} & \multicolumn{3}{|c|}{$\begin{array}{c}\text { 3rd } \\
\text { grade }\end{array}$} & \multicolumn{3}{|c|}{$\begin{array}{c}\text { 2nd } \\
\text { grade }\end{array}$} & \multicolumn{3}{|c|}{$\begin{array}{c}1 s t \\
\text { grade }\end{array}$} \\
\hline & 14.8 & 14 & 13.8 & 13.8 & 13 & 12.8 & 12.8 & 12 & 11.8 & 11.8 & 11 & 10.8 & 10.8 & 10 & 9.8 & 9.8 & 9 & 8.8 & 8.8 & 8 & 7.8 & 7.8 & 7 & 6.8 & 6.8 & 6 & 5.8 \\
\hline Birth date & $\begin{array}{l}\text { Apr. } \\
2000\end{array}$ & $\begin{array}{l}\text { P } \\
\text { Feb. } \\
2001\end{array}$ & $\overrightarrow{\substack{\text { Mar. } \\
2001}}$ & $\begin{array}{l}\text { Apr. } \\
2001\end{array}$ & $\begin{array}{l}\text { Peb. } \\
2002\end{array}$ & $\overrightarrow{\text { Mar. }_{2002}}$ & $\begin{array}{l}\text { Apr. } \\
2002\end{array}$ & $\begin{array}{l}\cdot \bullet \\
\text { Feb. } \\
2003\end{array}$ & $\begin{array}{l}{ }_{\text {Mar. }} \\
2003\end{array}$ & $\begin{array}{l}\text { Apr. } \\
2003\end{array}$ & $\begin{array}{l}\cdot \\
\text { Feb. } \\
2004\end{array}$ & $\begin{array}{c}\underset{\text { Mar. }}{2004} \\
.\end{array}$ & $\begin{array}{c}\text { Apr. } \\
2004\end{array}$ & $\begin{array}{c}\bullet \\
\text { Feb } \\
2005\end{array}$ & $\overrightarrow{{ }_{2005}}$ & Apr. & $\begin{array}{c}\stackrel{\bullet}{F_{e b}} \\
2006\end{array}$ & $\overrightarrow{{ }_{2006}^{\text {Mar. }}}$ & Apr. & $\begin{array}{l}\cdot \\
\text { Feb. } \\
2007\end{array}$ & $\overrightarrow{\text { Mar. }_{2007}}$ & $\begin{array}{l}\text { Apr. } \\
2007\end{array}$ & $\begin{array}{c}\stackrel{\bullet}{\text { Feb. }} \\
2008\end{array}$ & $\overrightarrow{\text { Mar. }}$ & Apr. & $\begin{array}{l}\qquad \\
\begin{array}{l}\text { Feb. } \\
2009\end{array}\end{array}$ & $\begin{array}{l}\text { Mar. } \\
2009\end{array}$ \\
\hline \multicolumn{28}{|c|}{$\begin{array}{l}\longrightarrow \text { Later enrollment in primary school (older than 6) } \\
\longrightarrow \text { Early enrollment in primary school (younger than 6) }\end{array}$} \\
\hline
\end{tabular}

Fig. 1. Late versus early primary school enrolment in Brazil (theoretical age for a cut-off date of March 31 and a school year starting on February 1). Source: The author's analyses.

(measured by professionals using standard equipment in a dedicated session). ${ }^{5}$

To exclude children not eligible by the 2006's educational reform (which changed the compulsory age of primary school entry), I focused on middle school children who were at least 6 years old in 2006 (eligible to the reform), i.e. those who were born from 2000 to 2004 and were between 11 and 15 years old in 2015 .

\subsection{Model}

Let consider the following structural linear model:

$\mathrm{Y}_{\mathrm{i}}=\beta_{0}+{ }_{1}$ LateEnrollment $_{\mathrm{i}}+\beta_{2} \mathrm{X}_{\mathrm{i}}+\varepsilon_{\mathrm{i}}$

$Y_{i}$ refers to nutritional and health outcomes of an individual $i$, including: (i) the body mass index (BMI) adjusted for age and gender using the World Health Organization (WHO, 2006) correction (z-score), ${ }^{6}$ (ii) the BMI clinical classification directly measured by the survey staff using the (WHO, 2006) correction (e.g. overweight, and underweight dummies), ${ }^{7}$ (iii) the height-for-age (z-score), and (iv) a dummy of moderate stunting (equal to 1 if height-for-age $<-2$ z-scores, 0 otherwise). In the literature, BMI is considered a short-term indicator of nutritional status since weight depends to a great extent on current food consumption and lifestyle (Thomas et al., 1991). In contrast, height-for-age is considered a long-term indicator of health status since physical growth strongly reflects nutritional deprivation and maternal risk behaviours from gestation to early childhood (Thomas et al., 1991).

$X_{i}$ refers to the observed characteristics of an individual $i$. In accordance with the existing literature analysing the socio-environmental causes of child nutritional statuses (e.g. Pongou et al., 2006), I control for individual and family characteristics. At the individual level, I take standard demographic factors into account: gender and race (white, black, Asian, mixed, or Amerindian). At the household level, I control for socio-demographic factors including household size, a household wealth index summing owned assets (as a proxy of family income), ${ }^{8}$ and the mother's education level. Finally, I include school fixed effects and birth month fixed effects interacted with where the school is located in Brazil (North, North-East, South-East, South or Centre-West) to neutralize area- and time-specific heterogeneity (e.g. cultural, geographical, and

\footnotetext{
5 This is not the case for the first sample of PeNSE 2015, which included more than 100,000 students in the final grade of middle school $\left(9^{\circ}\right.$ ano do ensenino basico).

${ }^{6}$ Before z-score adjustment, individual BMI was obtained dividing weight $(\mathrm{kg})$ by squared height $(\mathrm{m})$.

7 The adjusted childhood underweight and overweight thresholds correspond to a standard adult equivalent (i.e. $<18.5$ for underweight status and $>25 \mathrm{~kg}$ / $\mathrm{m}^{2}$ for overweight status).

8 The wealth index is a 5-score index summing the five following assets if owned by household: home landline, a personal mobile phone, home computer, Internet access at home, and a car owned by the household.
}

climate heterogeneity).

LateEnrollment $t_{i}$ refers to the enrollment status, which, for each grade, distinguishes younger peers (early enrollment) from older peers (late enrollment). In Brazil, the school year generally starts in February and ends in December. Assuming that the school year starts in February for all Brazilian middle schools, this means that a child born at the beginning of February would start primary school around age 6, a child born between February and the cut-off date (oscillating between March and April depending on states and municipalities) would start before age 6 (i. e. around age 5.5), but a child born after the cut-off date will start primary school 1 year older (i.e. around age 6.5). The state- and municipalspecific administrative rules for primary school enrolment create a fuzzy discontinuity in the birth month distribution by introducing a 1-year gap in primary school enrolment between children born before and after the cut-off date. Since the exact cut-off date is unknown for each school of the sample, I use a calculation to proxy school starting age and distinguish between early and late enrolment based on the age of children when school started (i.e. assuming February as school year starting date). Specifically, using reported birthdate (in month and year) and information on the grade of each individual $i$ in 2015, I attribute the value 0 if a child was born after February $f$ years ago (i.e. younger than 6 years old when enrolled in primary school), and the value 1 if a child was born before February $f$ years ago (i.e. older than 6 years old when enrolled in primary school). $f$ is the theoretical number of years between

Table 1

Sample distribution across school grades (frequencies).

\begin{tabular}{llll}
\hline Grade & Late enrolment & Early enrolment & Total \\
\hline Middle school (6th grade) & 1943 & 577 & 2520 \\
Middle school (7th grade) & 2196 & 740 & 2936 \\
Middle school (8th grade) & 1386 & 1033 & 2419 \\
Middle school (9th grade) & 751 & 671 & 1422 \\
Total & 6276 & 3021 & 9297 \\
\hline
\end{tabular}

Source: PeNSE 2015, Sample 2.

birth and a given school grade (i.e. the expected age of a child for each school grade based on the administrative rule). In Brazil, $f$ takes the values $11,12,13$, and 14 for grades $6,7,8$, and 9 of primary school (i.e. middle school), respectively. Fig. 1 clearly illustrates how each individual in the database is classified between early enrolment $(=0)$ and late enrolment $(=1)$. Table 1 lists the number of observations for both enrolment statuses, and Fig. 2 shows the density functions for each 


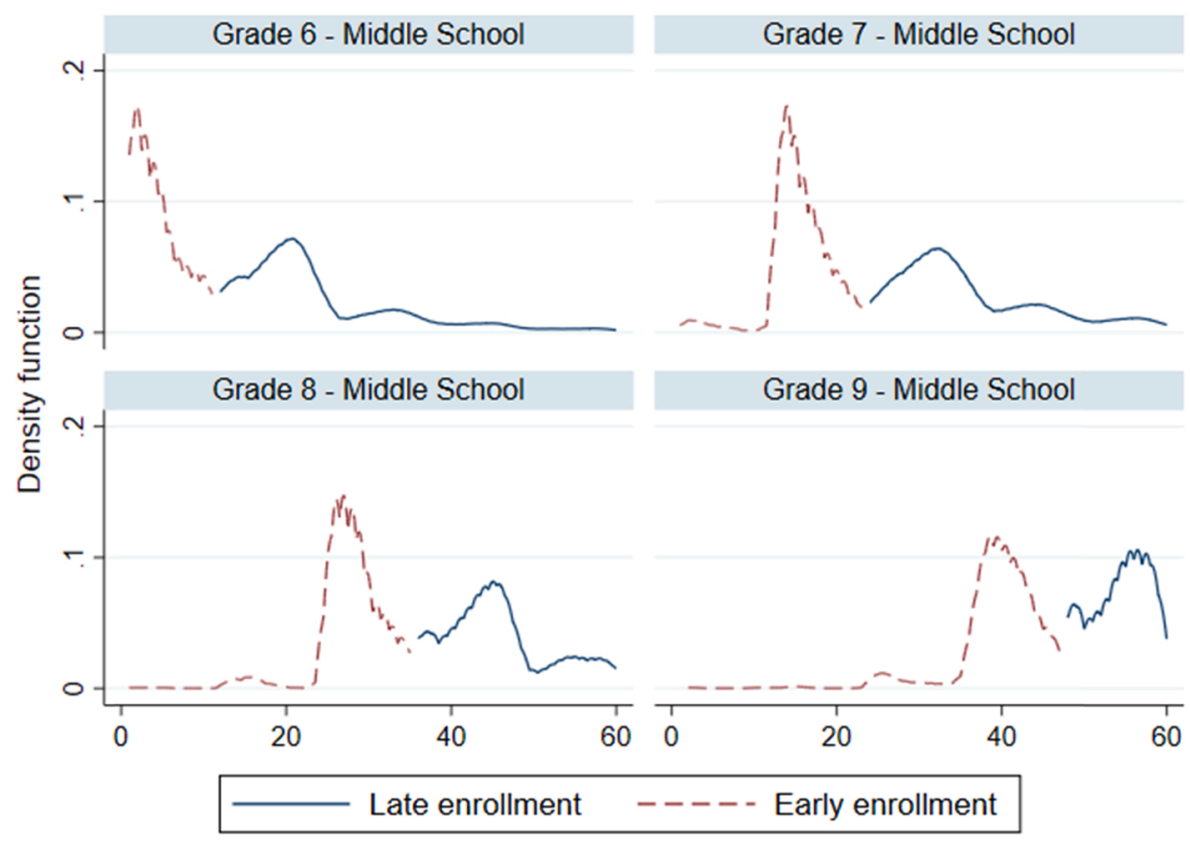

Fig. 2. Density functions of birthdate across enrolment status for each grade. Notes: The Y-line represents a kernel density function of students per grade. The X-line represents birthdate, in month per year centred on the cut-off that splits early and late enrolment in school (i.e. February). For instance, value 1 refers to February 2004, value 11 refers to December of 2004, value 12 to January of 2003, up to value 60 that refers to January 1999.

Source: PeNSE 2015, Sample 2.

grade. $^{9}$

\subsection{Identification strategy}

In the study context, the identification of causal effects involves notable statistical complications. More specifically, endogeneity bias may influence the relationship between school starting age and nutritional outcomes. Indeed, parents might voluntarily delay school enrolment of weak children (e.g. suffering from specific illness or characterized by a lower height-for-age or lower weight-for-age). For instance, Alderman et al. (2009) observed that stunted children in Tanzania have a higher probability of delayed enrolment than healthy children. Such an endogeneity problem would tend to overstate the positive effect of school starting age on stunting and underweight because there is a potential overrepresentation of stunted and underweight children who enrolled school older.

Statistically speaking, it could be possible to use the 1-year jump between children born in March and April of the same year to identify the effects of a delayed school start on nutritional indicators. Unfortunately, although most of states chose between February and April as cut-

\footnotetext{
${ }^{9}$ Obviously, schools and parents do not systematically meet the Brazilian rule of primary school starting age. As shown in Table 1, there are more lateenrolled students in the sample since this group is likely to include students whose parents (intentionally or not) delayed school enrollment. Moreover, since I use a calculation to proxy school starting age and distinguish early/late enrollments (there is no information about actual school starting age), some students are mechanically misclassified: all students who repeated a grade are classified into the late enrollment group, and the few students who skipped a grade are presumably included in the early enrollment group. This fuzzy allocation of early- and late-enrolled students in the sample justifies the use of twostep IV regressions. To check for the robustness of the results against these misclassification errors, I ran non-reported estimates restricting the sample to students who have the correct age for the correct grade (hence excluding students who repeated or skipped a grade). Similar results were obtained.
}

off date (Ryu et al., 2020), the fuzzy allocation of early- and late-enrolled children across states makes the use of a regression discontinuity design impossible. Hence, to deal with potential endogeneity problems, I opt for a two-stage least squares estimator based on an IV approach inspired by Bedard and Dhuey (2006) and Angrist and Krueger (1991). More specifically, I use birthdate (month and year) as an exogenous determinant of school starting age (early versus late enrolments), which is relative to grade information and the school cut-off date. Theoretically, the birthdate is a good instrument to neutralize the suspected endogeneity caused by the parental decision to delay school entry of weak children. Indeed, one can assume a quasi-random distribution of birthdate in pre-existing nutritional status (before school enrolment) and the parental decision to delay school entry, so there is no direct link between birthdate and current nutritional status. More formally, the two-step IV model is formulated as follows:

$\left\{\begin{array}{c}\mathrm{Y}_{\mathrm{i}}=\delta_{0}+\delta_{1} \text { LateEnrollment }_{\mathrm{i}}+\delta_{2} \mathrm{X}_{\mathrm{i}}+\partial_{\mathrm{i}} \\ \text { with } \text { LateEnrollment }_{\mathrm{i}}=\gamma_{0}+\gamma_{1} \mathrm{IV}_{\mathrm{i}}+\gamma_{2} \mathrm{X}_{\mathrm{i}}+\mathrm{u}_{\mathrm{i}}\end{array}\right\}$

As modelled above, a first-stage estimation is used to introduce fitted values of enrolment status (LateEnrollment $\mathrm{t}_{\mathrm{i}}$ ) uncorrelated with residuals $\left(\partial_{\mathrm{i}}\right)$ in a second-stage equation. Such an IV strategy relies on the introduction of instruments in first-stage estimates, which must be strong predictors of enrolment status (relevance condition) but uncorrelated with residuals (exclusion restriction condition). In other words, if the selected instruments meet both conditions, $\delta_{1}$ refers to the effect of exogenous variations in delayed enrolment on nutritional outcomes. Like Bedard and Dhuey (2006), I use birthdate data to instrument enrolment status measured in dummies of birth month per year. There are 12 birth months per year, and the sample includes children born from 2000 to 2004 (a 5-year period), corresponding to 60 birth month dummies.

The first validity condition for an instrument is to be a strong predictor of the assumed endogenous regressor, i.e. delayed school enrolment. Bound et al. (1995) questioned the strength of birth season as an 
instrument in the study context of Angrist and Krueger (1991). However, the first-stage estimates run here are not affected by such a weakness problem. As shown in first-stage estimates reported in Table 2, each birth month dummy has a significant effect on the probability of delayed enrolment in primary school (at the $1 \%$ level), and F-statistics and partial R-square values on excluded instruments are both high. According to Bound et al. (1995), both latter indicators are useful to assess the strength of an instrument. ${ }^{10}$

Second, to be valid, IV estimates must comply with the exclusion restriction condition. It means that variations in enrolment status induced by birthdate variations are uncorrelated with unobserved variations in health and nutritional outcomes. Unfortunately, the exclusion restriction assumption is not directly testable and always remains debatable. This assumption could be violated if children born at different times have higher or lower unobserved height-for-age or BMIfor-age. For instance, ethnicity-specific seasonality in conception behaviours might be a concern (Buckles and Hungerman, 2012), especially in a country like Brazil where racial segregation is still common (Dressler et al., 1998). Likewise, as highlighted by Buckles and Hungerman (2012), since family backgrounds are highly correlated to season-of-birth and later outcomes, there is a risk that birthdate does not satisfy the exclusion restriction condition. For example, numerous families are likely to have a certain conception experience and might thus schedule the pregnancy to limit negative externalities such as affecting career plans. To limit this potential source of bias associated with racial and family backgrounds, I control the estimates (everything being equal) for race, family composition, and socioeconomic backgrounds. In addition, I systematically include school fixed effects and birth month fixed effects interacted with regions to alleviate potential direct correlations between the instruments (birthdate) and current nutritional outcomes.

Another potential concern that might violate the exclusion restriction condition relies on parental manipulation of conception or birthdate, with a view to intentionally delay the future school enrolment of their children 6 years later (i.e. which could bias first-stage estimates). Brazil has one of the highest rates of caesarean-section (C-section) births in the world, representing half of all deliveries in the country (Boerma et al., 2018). The authors observed that the C-section rates in Brazil are the highest among mothers with high education levels. However, even if informed and educated parents can theoretically manipulate childbirth by controlling conception periods and/or opting for assisted deliveries (e.g. scheduling a C-section), it is unlikely they would intentionally schedule births to delay future school enrolment and maximize the child's educational success (expecting a readiness effect for example). Using a large database from Chile, which has a similar C-section rate, McEwan and Shapiro (2008) found no evidence of birthdate manipulation near the enrolment cut-off. Notwithstanding the presumed absence of birth manipulation, I checked for continuity of the birth month distribution around the administrative cut-off that separates early- and late-enrolled students in Brazil. I found no evidence of birth manipulation in the data. ${ }^{11}$

\footnotetext{
10 Given the presence of students and/or Brazilian states that did not comply with the law (regarding the cut-off date for school entry), the prediction is not perfect: fitted coefficients of birth month dummies are different from 1.0 that would be obtained with perfect compliance with the law.

11 A McCrary (2008) test revealed no significant distribution gap near the cut-off, indicating that the model is not biased by manipulation problems. Similarly, the Frandsen (2017) manipulation test, which is appropriate for discrete running variables, showed no significant gap regarding birth month around the cut-off ( $\mathrm{p}$-value $=0.779$ ).
}

\section{Results}

\subsection{Descriptive statistics}

The restricted sample includes more than 9000 middle school students aged between 11 and 15 (born after 2000) classified as early or late enrolment in primary school according to their birthdate and grade information (Table 1). Table 3 presents the sample means for all observed characteristics used in this study, according to enrolment status. It is worth noting that overweight children are now common in Brazil, with around $29 \%$ of the sample (middle school students aged from 11 to 15) classified as overweight in 2015. Underweight status is less prevalent but persists marginally (around 3\%), and height-for-age in $\mathrm{z}$-scores is positive but close to 0 , suggesting a small proportion of stunting in Brazil (around 1\% in the sample). Table 3 shows notable differences across school enrolment status. Both BMI-for-age and heightfor-age are higher among early-enrolled students (relatively younger than their grade peers) compared to later-enrolled students (relatively older than their grade peers). As explained earlier, the overrepresentation of children with lower height-for-age and BMI-for-age among later-enrolled students might be due to endogeneity in the relationship between enrolment status and health status. Indeed, some parents might prefer to keep their children with poor health (being smaller and thinner on average) at home longer, consequently delaying school entry. As shown in Table 3, Black and Mixed children born to mothers with low education are more likely to enrol later. In theory, the overrepresentation of initially healthier students from privileged households in the early enrolment group is likely to bias the effects of late enrolment on BMI-for-age and height-for-age. For this reason, multivariate estimates coupled with an IV strategy is used in the following section.

\subsection{IV estimates}

Table 4 lists IV estimates of the impacts of late enrolment (vs. early enrolment) on nutritional outcomes. In column 1, the whole sample is regressed. Gender-specific estimates are given in columns 2 and 3. In columns 4 and 5, I test for a heterogeneous effect based on the mother's education, distinguishing little education (if the mother did not go beyond middle school) from higher educational level (if the mother at least attended high school). Complete Table 4 is available in Table A1 in Online Appendix.

Overall, Table 4 shows that late-enrolled children have lower BMIfor-age than their peers who enrolled younger, per $0.14 \mathrm{z}$-score unit. Table 4 clearly reveals gender-specific effects regarding BMI-for-age, highlighting a stronger impact among boys (a reduction of $0.21 \mathrm{z}$ score unit for BMI-for-age and a reduction of overweight risk by $5.9 \%$ points). Moreover, I also detected a heterogeneous effect according to family backgrounds. Delayed enrolment increases the probability of being classified as normal weight among students with educated mothers (i.e. reducing the risks of underweight and overweight).

In contrast, Table 4 shows a negative effect of late enrolment on height-for-age $(-0.30 \mathrm{z}$-score unit), which significantly increases the risk of moderate stunting by $1.5 \%$ points. Even if gender-specific results are unclear, there is clear heterogeneity according to family background. Among students with low-educated mothers, late enrolment significantly increases the risk of stunting by $4.9 \%$ points and height-forage by $0.74 \mathrm{z}$-score unit, while respective fitted coefficients are significantly lower among students with educated mothers.

\section{Conclusion}

This article analysed the impact of delayed school enrolment on nutritional and health statuses some years later, considering both stunting and excess weight indicators. Specifically, to assess the impact of late enrolments on BMI-for-age and height-for-age among a sample of 
Table 2

First step regressions of late enrolment on instruments and covariates.

\begin{tabular}{|c|c|c|c|c|c|}
\hline Dependent outcome: Delayed enrolment & Whole sample & Female & Male & Better educated mother & Mother with little education (incl. DKN) \\
\hline Male (dummy) & $\begin{array}{l}0.020 * \\
(0.010)\end{array}$ & & & $\begin{array}{l}0.023 * \\
(0.013)\end{array}$ & $\begin{array}{l}0.045 * * * \\
(0.010)\end{array}$ \\
\hline Black (dummy) & $\begin{array}{l}0.051 * * \\
(0.017)\end{array}$ & $\begin{array}{l}0.080 * * * \\
(0.024)\end{array}$ & $\begin{array}{l}0.015 \\
(0.027)\end{array}$ & $\begin{array}{l}0.042 * \\
(0.023)\end{array}$ & $\begin{array}{l}0.048 * * * \\
(0.015)\end{array}$ \\
\hline Asian (dummy) & $\begin{array}{l}0.023 \\
(0.026)\end{array}$ & $\begin{array}{l}0.022 \\
(0.033)\end{array}$ & $\begin{array}{l}0.023 \\
(0.031)\end{array}$ & $\begin{array}{l}0.008 \\
(0.044)\end{array}$ & $\begin{array}{l}0.048 * \\
(0.026)\end{array}$ \\
\hline Mixed (dummy) & $\begin{array}{l}0.011 \\
(0.013)\end{array}$ & $\begin{array}{l}0.015 \\
(0.017)\end{array}$ & $\begin{array}{l}0.006 \\
(0.014)\end{array}$ & $\begin{array}{l}0.011 \\
(0.017)\end{array}$ & $\begin{array}{l}0.032 * * \\
(0.012)\end{array}$ \\
\hline Amerindian (dummy) & $\begin{array}{l}0.008 \\
(0.020)\end{array}$ & $\begin{array}{l}-0.004 \\
(0.031)\end{array}$ & $\begin{array}{l}0.026 \\
(0.040)\end{array}$ & $\begin{array}{l}0.034 \\
(0.039)\end{array}$ & $\begin{array}{l}0.006 \\
(0.017)\end{array}$ \\
\hline Household size (number) & $\begin{array}{l}0.003 \\
(0.003)\end{array}$ & $\begin{array}{l}-0.004 \\
(0.006)\end{array}$ & $\begin{array}{l}0.008 * * \\
(0.003)\end{array}$ & $\begin{array}{l}-0.001 \\
(0.005)\end{array}$ & $\begin{array}{l}0.010 * * * \\
(0.002)\end{array}$ \\
\hline Basic education (dummy) & $\begin{array}{l}-0.039 * * * \\
(0.012)\end{array}$ & $\begin{array}{l}-0.030 \\
(0.029)\end{array}$ & $\begin{array}{l}-0.054 \\
(0.033)\end{array}$ & & $\begin{array}{l}-0.153 * * * \\
(0.021)\end{array}$ \\
\hline High school (dummy) & $\begin{array}{l}-0.052 * * * \\
(0.016)\end{array}$ & $\begin{array}{l}-0.019 \\
(0.028)\end{array}$ & $\begin{array}{l}-0.081 * \\
(0.037)\end{array}$ & & \\
\hline University (dummy) & $\begin{array}{l}-0.061 * * * \\
(0.016)\end{array}$ & $\begin{array}{l}-0.078 * * \\
(0.029)\end{array}$ & $\begin{array}{l}-0.057 \\
(0.042)\end{array}$ & $\begin{array}{l}-0.002 \\
(0.015)\end{array}$ & \\
\hline DKN (dummy) & $\begin{array}{l}-0.018 \\
(0.018)\end{array}$ & $\begin{array}{l}-0.024 \\
(0.030)\end{array}$ & $\begin{array}{l}-0.013 \\
(0.039)\end{array}$ & & $\begin{array}{l}-0.110 * * * \\
(0.025)\end{array}$ \\
\hline Wealth index (5-point score) & $\begin{array}{l}-0.014 * * * \\
(0.002)\end{array}$ & $\begin{array}{l}-0.015 * * \\
(0.005)\end{array}$ & $\begin{array}{l}-0.012 * * \\
(0.004)\end{array}$ & $\begin{array}{l}-0.021 * * \\
(0.007)\end{array}$ & $\begin{array}{l}-0.010 * * * \\
(0.002)\end{array}$ \\
\hline Instruments (birthdate) & YES*** & YES*** & YES*** & YES*** & YES*** \\
\hline Birth month fixed effects interacted with regions & YES & YES & YES & YES & YES \\
\hline School fixed effects & YES & YES & YES & YES & YES \\
\hline Constant & $\begin{array}{l}0.210 * * \\
(0.088)\end{array}$ & $\begin{array}{l}0.329 * \\
(0.163)\end{array}$ & $\begin{array}{l}0.196 * * \\
(0.076)\end{array}$ & $\begin{array}{l}0.183 * * \\
(0.068)\end{array}$ & $\begin{array}{l}0.401 * * \\
(0.147)\end{array}$ \\
\hline Observations & 9215 & 4574 & 4641 & 3880 & 8301 \\
\hline R-squared & 0.575 & 0.577 & 0.619 & 0.623 & 0.479 \\
\hline Partial R-squared on excluded instruments & 0.391 & 0.381 & 0.417 & 0.413 & 0.281 \\
\hline F-statistic on excluded instruments & 1108.66 & 1192.28 & 604.99 & 1268.84 & 491.25 \\
\hline P-value & 0.000 & 0.000 & 0.000 & 0.000 & 0.000 \\
\hline
\end{tabular}

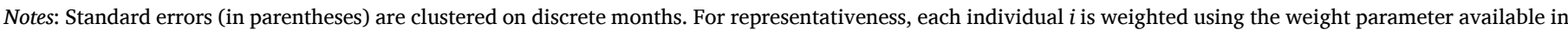

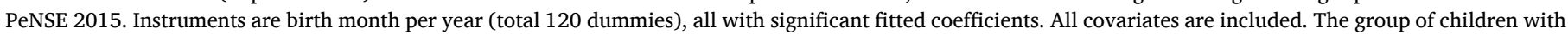

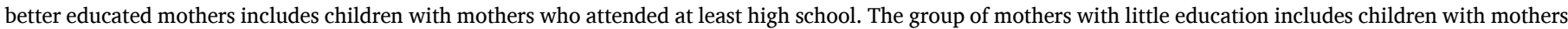

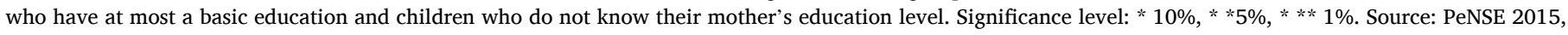
Sample 2.

Table 3

Sample means across enrolment status.

\begin{tabular}{llll}
\hline & Early enrolment & Late enrolment & All students \\
\hline BMI-for-age (z-score) & 0.45 & 0.38 & 0.40 \\
Underweight (dummy) & 0.03 & 0.03 & 0.03 \\
Overweight (dummy) & 0.30 & 0.28 & 0.29 \\
Height-for-age (z-score) & 0.45 & 0.31 & 0.36 \\
Stunting (dummy) & 0.01 & 0.01 & 0.01 \\
Male (dummy) & 0.45 & 0.54 & 0.51 \\
Black (dummy) & 0.10 & 0.15 & 0.13 \\
Asian (dummy) & 0.05 & 0.04 & 0.04 \\
Mixed (dummy) & 0.40 & 0.43 & 0.42 \\
Amerindian (dummy) & 0.04 & 0.04 & 0.04 \\
Household size (number) & 4.44 & 4.63 & 4.56 \\
Basic education (dummy) & 0.20 & 0.23 & 0.22 \\
High school (dummy) & 0.22 & 0.18 & 0.19 \\
University (dummy) & 0.23 & 0.15 & 0.18 \\
DKN (dummy) & 0.32 & 0.36 & 0.35 \\
Wealth index (5-point score) & 3.58 & 3.10 & 3.26 \\
\hline
\end{tabular}

Notes: Each individual $i$ is weighted using the weight parameter available in PeNSE 2015.

Source: PeNSE 2015, Sample 2.

middle school students aged between 11 and 15, I implemented IV estimates based on the quasi-randomness of birthdate that determines school starting age in Brazil.

The results indicate that delayed school entrance may affect both BMI-for-age and height-for-age indicators some years later. More importantly, they clearly highlight heterogeneous effects according to social backgrounds. Indeed, significant harmful effects were found among children from socially deprived backgrounds, for whom delayed enrolment was associated with lower height-for-age and BMI-for-age and higher risk of stunting. In contrast, delayed enrolment tends to have protective effects for children with more educated mothers, reducing the risks of being underweight and overweight (but not significantly increasing the risk of stunting).

Several reasons may explain these nutritional inequalities associated with school starting age. Delaying school enrolment may incur higher costs that make the family more vulnerable to economic shocks, for instance by increasing childcare expenditures and limiting parental employment and earnings (McEwan and Shapiro, 2008). These economic shocks could have led to food deprivations and nutritional deficiencies in the past, thereby impairing children's physical and intellectual growth. Another explanation could be the longer exposure of late-enrolled students to (nutritionally poor) family meals and delayed access to dietetic school meals, as evidenced in the literature on nutrition (Gelli et al., 2019; Horta et al., 2019). Indeed, early school enrolment implies earlier access to free school meals, which is likely to offset family food deprivations during child growth and reduce the risks of unhealthy food intakes (von Hippel et al., 2007; Anderson et al., 2011).

The results also emphasized gender-specific trends. I found that younger enrolment in primary school (i.e. before 6 years old) significantly increases BMI-for-age and the risk of childhood overweight, especially for boys, which is consistent with the literature reporting beneficial impacts of late enrolment on educational outcomes among boys. In Chile, McEwan and Shapiro (2008) found higher risks of repeating first grade due to early enrolment among boys compared to girls. Citing works in psychology (Stipek, 2002), the authors speculated that boys of the same age might be less mature and less ready to absorb school contents than girls. The emotions associated with educational 
Table 4

Impacts of late enrolment (vs. early enrolment) on health and nutritional outcomes (IV estimates).

\begin{tabular}{|c|c|c|c|c|c|}
\hline & Whole sample & Male & Female & Better educated mother & Mother with little education (incl. DKN) \\
\hline \multirow[t]{3}{*}{ BMI-for-age (z-score) } & $-0.140 * *$ & $-0.213 *$ & -0.096 & -0.083 & $-0.167 * * *$ \\
\hline & $(0.071)$ & $(0.118)$ & $(0.076)$ & $(0.073)$ & $(0.048)$ \\
\hline & $N=9213$ & $N=4573$ & $N=4640$ & $N=3880$ & $N=8299$ \\
\hline \multirow[t]{3}{*}{ Underweight (dummy) } & 0.004 & 0.024 & -0.013 & $-0.017 * *$ & 0.015 \\
\hline & $(0.011)$ & $(0.020)$ & $(0.011)$ & $(0.009)$ & $(0.012)$ \\
\hline & $N=9215$ & $N=4574$ & $N=4641$ & $N=3880$ & $N=8301$ \\
\hline \multirow[t]{3}{*}{ Overweight (dummy) } & -0.045 & $-0.059 *$ & -0.029 & $-0.061 * *$ & -0.031 \\
\hline & $(0.028)$ & $(0.033)$ & $(0.030)$ & $(0.027)$ & $(0.028)$ \\
\hline & $N=9215$ & $N=4574$ & $N=4641$ & $N=3880$ & $N=8301$ \\
\hline \multirow[t]{3}{*}{ Height-for-age (z-score) } & $-0.300 * * *$ & -0.126 & $-0.474 * * *$ & $-0.186 * *$ & $-0.739 * * *$ \\
\hline & $(0.061)$ & $(0.080)$ & $(0.073)$ & $(0.089)$ & $(0.070)$ \\
\hline & $N=9212$ & $N=4571$ & $N=4641$ & $N=3879$ & $N=8299$ \\
\hline \multirow[t]{3}{*}{ Stunting (dummy) } & $0.015 * * *$ & $0.021 * *$ & 0.005 & 0.003 & $0.049 * * *$ \\
\hline & $(0.005)$ & $(0.009)$ & $(0.004)$ & $(0.007)$ & $(0.016)$ \\
\hline & $N=9212$ & $N=4571$ & $N=4641$ & $N=3879$ & $N=8299$ \\
\hline
\end{tabular}

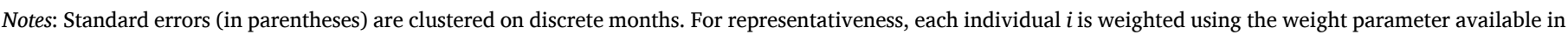

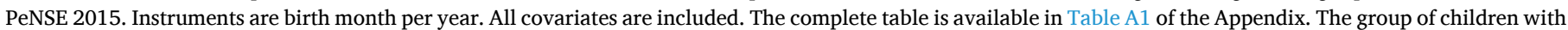

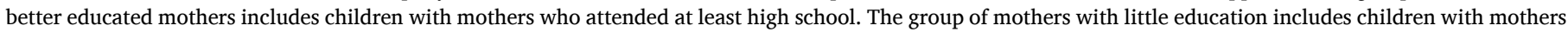

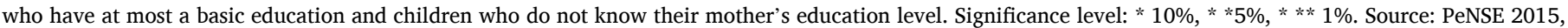
Sample 2 .

failure potentially affects nutrition and health outcomes by changing feeding behaviours (Goldston et al., 2007; Gustafsson et al., 2010). Hence, one can assume that the hazardous weight gain of early-enrolled boys in Brazil is partly driven by mental issues generated by increased educational failures. Furthermore, higher vulnerability of early-enrolled students to negative school externalities such as bullying (Black et al., 2011) may also explain their weight gain, increasing the risk of suffering from mental health troubles and nutritional disorders (Bauman et al., 2013).

In summary, this study emphasized the ambiguous impact of school starting age on health and nutritional outcomes in developing countries such as Brazil. Globally, there are notable nutritional benefits for enrolling later, probably thanks to greater readiness for absorbing school content, higher maturity to manage knowledge tests, and lower sensitivity to negative school externalities such as bullying. However, late enrolment may have several hidden costs for underprivileged students (e.g. higher childcare expenditures, longer mother unemployment, delayed exposure to school meals), which makes many Brazilian families highly vulnerable to economic shocks and food insecurity with children more prone to nutritional deprivation during growth.

The strong heterogeneity in nutritional issues that characterizes Brazilian schools renders the school enrolment policy inefficient. For instance, introducing a delay in primary school enrolment will probably disadvantage lower social groups. Hence, decision makers should act directly by providing free school meals, anti-bullying and anti-obesity campaigns, and social protection programs for poor families with young children. Future research should focus on empirically identifying effective transmission pathways. Likewise, additional investigations aiming to replicate this research using different databases are needed to test the generalization and robustness of the results. The main limitation is the lack of data about exact school starting age (leading to the calculation of a proxy based on some debatable assumptions). Specifically, the results could be affected by misclassification issues, since students who repeated a grade are misclassified as being late-enrolled. Hence, the inclusion of grade repeaters into the late enrolment group might overstate the harmful nutritional effects observed among underprivileged students, assuming that grade retention is correlated with poor child health.

\section{Funding sources}

This study did not beneficiated from specific funding support.

\section{Acknowledgements}

The database is publicly available online at: https://www.gov.br/sau de/pt-br/assuntos/saude-de-a-a-z/p/pesquisa-nacional-de-saude-do-es colar-pense, Data are anonymous and contain no personal information. The author is responsible for all errors. This study did not benefit from specific funding support. The author has no conflict of interest to declare. This research was supported by the INRAE program Global Food Security (GloFoodS).

\section{Conflict of interest statement}

The author has no conflict of interest to declare.

\section{Appendix A. Supporting information}

Supplementary data associated with this article can be found in the online version at doi:10.1016/j.ehb.2021.101104.

\section{References}

Alderman, H., Hoogeveen, H., Rossi, M., 2009. Preschool nutrition and subsequent schooling attainment: longitudinal evidence from Tanzania. Econ. Dev. Cult. Change 57 (2), 239-260. https://doi.org/10.1086/592875.

Anderson, P.M., Butcher, K.F., 2006. Reading, writing, and refreshments are school finances contributing to children's obesity? J. Hum. Resour. 3, 467-494. https://doi. org/10.3368/jhr.XLI.3.467.

Anderson, P.M., Butcher, K.F., Cascio, E.U., Schanzenbach, D.W., 2011. Is being in school better? The impact of school on children's BMI when starting age is endogenous. J. Health Econ. 30 (5), 977-986. https://doi.org/10.1016/j.jhealeco.2011.06.002.

Angrist, J.D., Krueger, A.B., 1991. Does compulsory school attendance affect schooling and earnings? Q. J. Econ. 106 (4), 979-1014. https://doi.org/10.2307/2937954.

Bahrs, M., Schumann, M., 2020. Unlucky to be young? The long-term effects of school starting age on smoking behavior and health. J. Popul. Econ. 33 (2), 555-600. https://doi.org/10.1007/s00148-019-00745-6.

Bakhshinyan, E., Molinas, L., Alderman, H., 2019. Assessing poverty alleviation through social protection: school meals and family benefits in a middle-income country. Glob. Food Secur. 23, 205-211. https://doi.org/10.1016/j.gfs. 2019.07.005.

Balestra, S., Eugster, B., Liebert, H., 2020. Summer-born struggle: the effect of school starting age on health, education, and work. Health Econ. 29 (5), 591-607. https:// doi.org/10.1002/hec.4005.

Bauman, S., Toomey, R.B., Walker, J.L., 2013. Associations among bullying, cyberbullying, and suicide in high school students. J. Adolesc. 36 (2), 341-350. https://doi.org/10.1016/j.adolescence.2012.12.001.

Bedard, K., Dhuey, E., 2006. The persistence of early childhood maturity: international evidence of long-run age effects. Q. J. Econ. 121 (4), 1437-1472.

Berlinski, S., Galiani, S., 2007. The effect of a large expansion of pre-primary school facilities on preschool attendance and maternal employment. Labour Econ. 14 (3), 665-680. https://doi.org/10.1016/j.labeco.2007.01.003.

Black, S.E., Devereux, P.J., Salvanes, K.G., 2011. Too young to leave the nest? The effects of school starting age. Rev. Econ. Stat. 93 (2), 455-467. 
Boerma, T., Ronsmans, C., Melesse, D.Y., Barros, A.J.D., Barros, F.C., Juan, L., Moller, A.B., Say, L., Hosseinpoor, A.R., Yi, M., Neto, D., de, L.R., Temmerman, M., 2018. Global epidemiology of use of and disparities in caesarean sections. Lancet 392 (10155), 1341-1348. https://doi.org/10.1016/S0140-6736(18)31928-7.

Bound, J., Jaeger, D.A., Baker, R.M., 1995. Problems with instrumental variables estimation when the correlation between the instruments and the endogeneous explanatory variable is weak. J. Am. Stat. Assoc. 90 (430), 443-450. https://doi.org/ $10.2307 / 2291055$.

Buckles, K.S., Hungerman, D.M., 2012. Season of birth and later outcomes: old questions, new answers. Rev. Econ. Stat. 95 (3), 711-724. https://doi.org/10.1162/REST_a_ 00314.

Chang, C., Jung, H., 2017. The role of formal schooling on weight in young children. Child. Youth Serv. Rev. 82, 1-12. https://doi.org/10.1016/j. childyouth.2017.09.005.

Datar, A., 2006. Does delaying kindergarten entrance give children a head start? Econ. Educ. Rev. 25 (1), 43-62. https://doi.org/10.1016/j.econedurev.2004.10.004.

Dee, T.S., Evans, W.N., 2003. Teen drinking and educational attainment: evidence from two-sample instrumental variables estimates. J. Labor Econ. 21 (1), 178-209. https://doi.org/10.1086/344127.

Dee, T.S., Sievertsen, H.H., 2018. The gift of time? School starting age and mental health. Health Econ. 27 (5), 781-802. https://doi.org/10.1002/hec.3638.

Doak, C.M., Adair, L.S., Monteiro, C., Popkin, B.M., 2000. Overweight and underweight coexist within households in Brazil, China and Russia. J. Nutr. 130 (12), 2965-2971.

Dressler, W.W., Balieiro, M.C., Santos, J.E.D., 1998. Culture, socioeconomic status, and physical and mental health in Brazil. Med. Anthropol. Q. 12 (4), 424-446. https:// doi.org/10.1525/maq.1998.12.4.424.

Evans, C.E.L., Mandl, V., Christian, M.S., Cade, J.E., 2016. Impact of school lunch type on nutritional quality of English children's diets. Public Health Nutr. 19 (1), 36-45. https://doi.org/10.1017/S1368980015000853.

Frandsen, B.R., 2017. Party bias in union representation elections: testing for manipulation in the regression discontinuity design when the running variable is discrete. Advances in Econometrics. Emerald Publishing Ltd., pp. 281-315. 〈https ://econpapers.repec.org/bookchap/emeaecozz/s0731-905320170000038012.htm /

Gelbach, J.B., 2002. Public schooling for young children and maternal labor supply. Am. Econ. Rev. 92 (1), 307-322.

Gelli, A., Aurino, E., Folson, G., Arhinful, D., Adamba, C., Osei-Akoto, I., Masset, E., Watkins, K., Fernandes, M., Drake, L., Alderman, H., 2019. A school meals program implemented at scale in ghana increases height-for-age during midchildhood in girls and in children from poor households: a cluster randomized trial. J. Nutr. 149 (8), 1434-1442. https://doi.org/10.1093/jn/nxz079.

Goldston, D.B., Walsh, A., Mayfield Arnold, E., Reboussin, B., Sergent Daniel, S., Erkanli, A., Nutter, D., Hickman, E., Palmes, G., Snider, E., Wood, F.B., 2007. Reading problems, psychiatric disorders, and functional impairment from mid- to late adolescence. J. Am. Acad. Child Adolesc. Psychiatry 46 (1), 25-32. https://doi. org/10.1097/01.chi.0000242241.77302.f4.

Graham, Hochfeld and Stuart, 2018, Double trouble: Addressing stunting and obesity via school nutrition, South African Journal of Child Health.

Gustafsson, J.-E., Allodi Westling, M., Alin Åkerman, B., Eriksson, C., Eriksson, L., Fischbein, S., Granlund, M., Gustafsson, P., Ljungdahl, S., Ogden, T., Persson, R.S., 2010. School, learning and mental health: a systematic review. K. Vetensk. 〈htt p://urn.kb.se/resolve?urn=urn:nbn:se:hj:diva-41913〉. von Hippel, P.T., Powell, B., Downey, D.B., Rowland, N.J., 2007. The effect of school on overweight in childhood: gain in body mass index during the school year and during summer vacation. Am. J. Public Health 97 (4), 696-702. https://doi.org/10.2105/ AJPH.2005.080754.

Horta, P.M., Carmo, A.S. do, Junior, E.V., Santos, L.C. dos, 2019. Consuming school meals improves Brazilian children's diets according to their social vulnerability risk. Public Health Nutr. 22 (14), 2714-2719. https://doi.org/10.1017/ S1368980019001459.

Leete, L., Bania, N., 2010. The effect of income shocks on food insufficiency. Rev. Econ. Househ. 8 (4), 505-526. https://doi.org/10.1007/s11150-009-9075-4.

Mak, H.-C. (Angela), 2018, June 12. Does School Starting Age Matter? The Impact of School on Childhood Obesity, Diet and Time Use in Australia. In: Proceedings of the 7th Annual Conference of the American Society of Health Economists. 〈https://ash econ.confex.com/ashecon/2018/webprogram/Paper6580.html $)$.

McCrary, J., 2008. Manipulation of the running variable in the regression discontinuity design: a density test. J. Econ. 142 (2), 698-714. https://doi.org/10.1016/j. jeconom.2007.05.005.

McEwan, P.J., Shapiro, J.S., 2008. The benefits of delayed primary school enrollment discontinuity estimates using exact birth dates. J. Hum. Resour. 43 (1), 1-29. https://doi.org/10.3368/jhr.43.1.1.

Mühlenweg, A., Blomeyer, D., Stichnoth, H., Laucht, M., 2012. Effects of age at school entry (ASE) on the development of non-cognitive skills: evidence from psychometric data. Econ. Educ. Rev. 31 (3), 68-76. https://doi.org/10.1016/j econedurev.2012.02.004.

Oliveira, M.M. de, Campos, M.O., Andreazzi, M.A.R. de, Malta, D.C., 2017. Características da Pesquisa Nacional de Saúde do Escolar - PeNSE. Epidemiol. Serv. Saúde 26, 605-616. https://doi.org/10.5123/S1679-49742017000300017.

Pongou, R., Ezzati, M., Salomon, J.A., 2006. Household and community socioeconomic and environmental determinants of child nutritional status in Cameroon. BMC Public Health 6 (1), 1-19. https://doi.org/10.1186/1471-2458-6-98.

Ryu, H., Helfand, S.M., Moreira, R.B., 2020. Starting early and staying longer: the effects of a Brazilian primary schooling reform on student performance. World Dev. 130, 104924 https://doi.org/10.1016/j.worlddev.2020.104924.

Schanzenbach, D.W., 2009. Do school lunches contribute to childhood obesity? J. Hum. Resour. 44 (3), 684-709. https://doi.org/10.3368/jhr.44.3.684.

Stipek, D., 2002. At what age should children enter kindergarten? A question for policy makers and parents. Soc. Policy Rep. 16 (2), 1-20. https://doi.org/10.1002/j.23793988.2002.tb00018.x.

Thibault, H., Carriere, C., Langevin, C., Kossi Déti, E., Barberger-Gateau, P., Maurice, S., 2013. Prevalence and factors associated with overweight and obesity in French primary-school children. Public Health Nutr. 16 (2), 193-201. https://doi.org/ 10.1017/S136898001200359X.

Thomas, D., Strauss, J., Henriques, M.-H., 1991. How does mother's education affect child height? J. Hum. Resour. 26 (2), 183-211. https://doi.org/10.2307/145920.

WHO. (2006). WHO child growth standards: length/height for age, weight-for-age, weight-for-length, weight-for-height and body mass index-for-age, methods and development. WHO Child Growth Standards: Length/Height for Age, Weight-forAge, Weight-for-Length, Weight-for-Height and Body Mass Index-for-Age, Methods and Development. 〈https://www.cabdirect.org/cabdirect/abstract/20063123347).

Zhang, N., Zhang, Q., 2011. Does early school entry prevent obesity among adolescent girls? J. Adolesc. Health. Off. Publ. Soc. Adolesc. Med. 48 (6), 644-646. https://doi. org/10.1016/j.jadohealth.2010.09.010. 